Revista Eletrônica Geografar, Curitiba, v. 2, Resumos do VI Seminário Interno de Pós-Graduação em Geografia, p. 17-17. Junho/2007

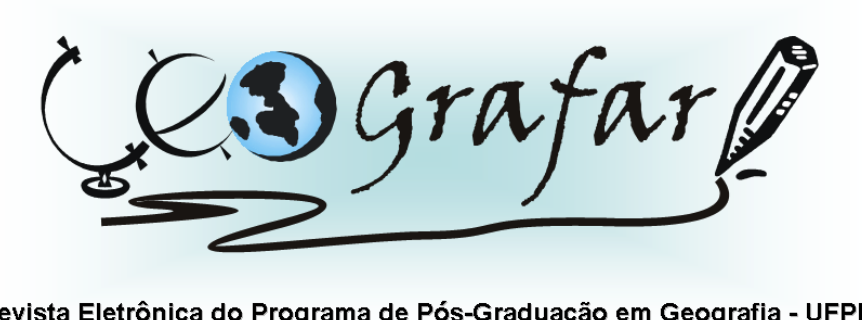

\title{
LEGISLAÇÃO AMBIENTAL NO MERCOSUL: UMA ANÁLISE GEOGRÁFICA DE BACIAS HIDROGRÁFICAS NA TRÍPLICE FRONTEIRA - BRASIL, ARGENTINA E PARAGUAI
}

\section{CRISTIANE GOMES ${ }^{1}$}

O presente estudo trata da análise da gestão de bacias hidrográficas, no âmbito do Mercosul, na área da fronteira paranaense entre o Brasil, Paraguai e a Argentina, conhecida como a Tríplice Fronteira. No que se refere à legislação ambiental desses países integrantes do Mercosul não existe uma convergência, principalmente nos aspectos referentes ao manejo das águas superficiais e subterrâneas. A visão estatal individualista relativa à legislação ambiental entre os membros do Cone Sul deve ser questionada, uma vez que nem todos os países pertencentes ao Bloco possuem o mesmo comprometimento em sua legislação ambiental, sendo que alguns não obedecem aos padrões mínimos de proteção dos seus mananciais, o que os diferencia do Brasil. Apesar das dificuldades em se aplicar a legislação, o modelo ambiental brasileiro possui uma razoável organização sistêmica, quando comparado aos outros integrantes do Mercosul. Além disso, alguns dos rios pertencentes à Bacia do Prata são compartidos entre esses países, havendo dessa maneira, a necessidade de se fazer um planejamento e gestão integrados, tendo em vista os problemas relacionados ao lixo, esgoto, desmatamento, expansão da fronteira agrícola, uso de agrotóxicos, loteamentos irregulares e outras questões que interferem no equilíbrio ambiental da região. Neste contexto, a análise geográfica, utilizando a abordagem sistêmica sobre a gestão de bacias no âmbito do Mercosul permite comparar as formas de organização da política ambiental desses países, tendo em vista que o meio ambiente não obedece às fronteiras estabelecidas pelos homens. Permite, também, apontar quais as medidas positivas em relação ao gerenciamento das águas, considerando as normas que asseguram o equilíbrio ambiental e o que deve ser mudado nos países integrantes do Bloco.

Palavras-chave: legislação ambiental; Mercosul, Tríplice Fronteira.

${ }^{1}$ Mestranda em Geografia - UFPR - email: crisassessoria@seed.pr.gov.br Orientadora: ANA MARIA MURATORI 